\title{
Erratum
}

Genome Research 28: 52-65 (2018)

Erratum: Deep experimental profiling of microRNA diversity, deployment, and evolution across the Drosophila genus

Jaaved Mohammed, Alex S. Flynt, Alexandra M. Panzarino, Md Mosharrof Hossain Mondal, Matthew DeCruz, Adam Siepel, and Eric C. Lai

In the above-mentioned article, one of the coauthor names was misspelled and has now been corrected online as Md Mosharrof Hossain Mondal.

doi: $10.1101 /$ gr.250654.119 


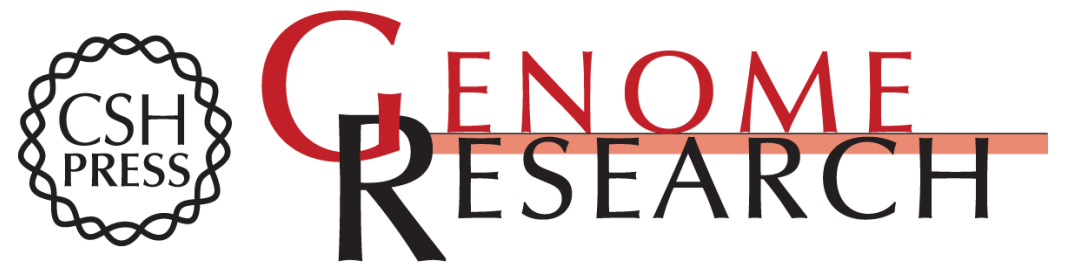

\section{Erratum: Deep experimental profiling of microRNA diversity, deployment, and evolution across the Drosophila genus}

Jaaved Mohammed, Alex S. Flynt, Alexandra M. Panzarino, et al.

Genome Res. 2019 29: 881

Access the most recent version at doi:10.1101/gr.250654.119

Related Content Deep experimental profiling of microRNA diversity, deployment, and evolution across the Drosophila genus

Jaaved Mohammed, Alex S. Flynt, Alexandra M. Panzarino, et al.

Genome Res. January, 2018 28: 52-65

Open Access Freely available online through the Genome Research Open Access option.

License

Email Alerting Receive free email alerts when new articles cite this article - sign up in the box at the Service top right corner of the article or click here.

\section{Affordable, Accurate} Sequencing.

To subscribe to Genome Research go to:

https://genome.cshlp.org/subscriptions 